\title{
Interelasi Pertumbuhan Ekonomi, Belanja Pendidikan dan Pengangguran Terhadap Tingkat Kemiskinan Jurnal Ecces
}

\author{
Siti Febriyanti Saputri ${ }^{1}$ \\ Puspita Hardianti Anwar ${ }^{2}$
}

Fakultas Ekonomi dan Bisnis Islam Universitas Islam Negeri Alauddin Makassar

Jl. Yasin Limpo, No. 36 Samata, Gowa, Sulawesi Selatan

E-mail : sitifebriyantisaputri@gmail.com¹, puspita.hardianti@uin-alauddin.ac.id²

\section{Abstrak: Pengaruh Pertumbuhan Ekonomi, Belanja Pendidikan dan Pengangguran Terhadap Tingkat Kemiskinan}

Belanja Pendidikan di Kabupaten Gowa semakin meningkat dari waktu ke waktu. Namun, di saat yang sama pertumbuhan justru melambat dengan tren yang menurun dalam 2 tahun terakhir, tepatnya di tahun 2015 hingga 2016. Di balik peningkatan belanja pendidikan yang terus meningkat, justru persentase penduduk miskin tidak mengalami perbaikan dan meningkat dalam waktu 3 tahun terakhir. Disi lain, pertumbuhan ekonomi di Kabupaten Gowa mengalami bertumbuh cukup fluktuatif, tahun 2012 data pertumbuhan ekonomi sebesar 7,40 persen dan pada tahun 2013 mengalami penurunan sebesar 7,33 persen. Sedangkan, tingkat pengangguran dalam lima tahun terakhir mengalami keadaan yang fluktuatif. Tahun 2012 jumlah pengangguran sebesar 4,01 persen dan menurun pada tahun 2013 menjadi 2,63 persen, kemudian tahun 2016 pengangguran mengalami penurunan sebesar 1,16 persen. Namun kemiskinan di Kabupaten Gowa justru naik pada tahun 2016 menjadi sebesar 8,40 persen. Penelitian ini merupakan penelitian yang bersifat kuantitatif yang menjelaskan pengaruh variabel bebas (independen) terhadap variabel terikat (dependen). Penelitian ini dilakukan di Kabupaten Gowa. Metode yang dipakai dalam pengumpulan data adalah melalui studi pustaka. Studi pustaka merupakan teknik untuk mendapatkan informasi melalui catatan, literatur, dokumentasi dan lain-lain yang masih relevan dalam penelitian ini. Data yang digunakan dalam penelitian ini adalah data sekunder yang diperoleh dalam bentuksudahjadi dari Badan Pusat Statistik di Provinsi Sulawesi Selatan. Hasil penelitian menunjukkan: Pertumbuhan Ekonomi (X1) berpengaruh negatif dan signifikan terhadap Kemiskinan (Y), Belanja Pendidikan (X2) berpengaruh negatif dan signifikan terhadap Kemiskinan $(Y)$, dan Pengangguran (X3) berpengaruh positif dan signifikan terhadap Kemiskinan ( $Y$ ).

Kata Kunci: Pertumbuhan Ekonomi, Belanja Pendidikan, Pengangguran dan Kemiskinan. 


\section{Abstract: Effect of Economic Growth, Education Expenditures and Unemployment Against Poverty level}

The problem of the stability price level of goods or inflation is still an economic problem that Education spending in Gowa Regency is increasing from time to time. However, at the same time growth has slowed down with a downward trend in the last 2 years, precisely in 2015 to 2016. Behind the increasing increase in education spending, the percentage of poor people has not improved and has increased in the last 3 years. On the other hand, economic growth in Gowa Regency experienced a fairly volatile growth, in 2012 data on economic growth was 7.40 percent and in 2013 it decreased by 7.33 percent. Meanwhile, the unemployment rate in the last five years has been fluctuating. In 2012 the number of unemployed was 4.01 percent and decreased in 2013 to 2.63 percent, then in 2016 unemployment decreased by 1.16 percent. However, poverty in Gowa Regency actually rose in 2016 to 8.40 percent. This research is a quantitative research that explains the effect of independent variables on the dependent variable. This research was conducted in Gowa Regency. The method used in data collection is through literature study. Library study is a technique to obtain information through notes, literature, documentation and others that are still relevant in this study. The data used in this study are secondary data obtained in the form of the Central Statistics Agency in South Sulawesi Province. The results showed: Economic Growth (X1) had a negative and significant effect on Poverty (Y), Education Expenditures (X2) had a negative and significant effect on Poverty $(Y)$, and Unemployment (X3) had a positive and significant effect on Poverty $(Y)$.

Keywords: Growth, Education Expenditures, Unemployment and Poverty.

\section{PENDAHULUAN / INTRODUCTION}

Belanja Pendidikan di Kabupaten Gowa semakin meningkat dari waktu ke waktu. Namun, disaat yang sama pertumbuhan justru melambat dengan tren yang menurun dalam 2 tahun terakhir, tepatnya di tahun 2015 hingga 2016. Di balik peningkatan belanja pendidikan yang terus meningkat, justru persentase penduduk miskin tidak mengalami perbaikan dan meningkat dalam waktu 3 tahun terakhir. Pertumbuhan ekonomi di Kabupaten Gowa mengalami fluktuatif, tahun 2012 data pertumbuhan ekonomi sebesar 7,40 persen dan pada tahun 2013 meng-alami penurunan sebesar 7,33 persen. Namun, tahun 2016 pertumbuhan ekonomi mencapai sebesar 7,63 persen. Sedangkan, terkait dengan data kemiskinan di Kabupaten Gowa tahun 2012 mencapai 8,06 persen dan mengalami peningkatan sebesar 8,73 persen. Di tahun berikutnya peningkatan pertumbuhan ekonomi yang cukup tinggi seharusnya dapat diikuti dengan penurunan persentase kemiskinan.

Belanja pendidikan tahun 2012 sebesar Rp.415.668.566,-sedangkan tahun 2013 mengalami peningkatan sebesar Rp 515.666.414,- dan terus mengalami fluktuasi hingga tahun 2016 kembali mengalami peningkatan yaitu sebesar Rp572.554.683,-. Peningkatan 
belanja pendidikan merupakan kebijakan pemerintah yang fokus untuk memperbaiki kesejahteraan rakyat dan juga golongan miskin yang ada. Belanja pendidikan idealnya bukan besaran atau volumenya saja yang penting adalah ketetapan penggunaanya. Namun, hal ini belum murni terealisasi di Kabupaten Gowa. Tingkat pengagguran pada lima tahun terakhir mengalami keadaan yang fluktuatif. Tahun 2012 jumlah pengagguran sebesar 4,01 persen dan menurun pada tahun 2013 menjadi 2,63 persen, kemudian tahun 2016 pengangguran mengalami penurunan sebesar 1,16 persen. Namun kemiskinan di Kabupaten Gowa justru naik pada tahun 2016 menjadi sebesar 8,40 persen. Pengangguran merupakan salah satu masalah yang cukup penting dibahas karena jika seseorang menganggur/tidak memiliki pekerjaan, artinya standar hidup seseorang akan turun karena tidak memiliki pendapatan untuk memenuhi ke-butuhan hidupnya. Selain itu, ketika pertumbuhan penduduk yang tinggi kemudian diimbangi dengan lapangan pekerjaan yang bertambah maka pengangguran di Kabupaten Gowa akan menurun.

Tabel 1

Pertumbuhan Ekonomi, Belanja Pendidkan, Pengangguran dan Kemiskinan Kabupaten Gowa Tahun 2012-2016

\begin{tabular}{ccccc}
\hline Tahun & $\begin{array}{c}\text { Persentase } \\
\text { Pertumbuhan } \\
\text { Ekonomi (\%) }\end{array}$ & $\begin{array}{c}\text { Belanja } \\
\text { Pendidikan } \\
\text { (Milyar) }\end{array}$ & $\begin{array}{c}\text { Persentase } \\
\text { Pengangguran } \\
(\%)\end{array}$ & $\begin{array}{c}\text { Persentase } \\
\text { Kemiskinan (\%) }\end{array}$ \\
\hline 2012 & 7,40 & 415.668 .566 & 4,01 & 8,06 \\
\hline 2013 & 7,33 & 515.666 .414 & 2,63 & 8,73 \\
\hline 2014 & 9,00 & 515.428 .919 & 2,32 & 8,00 \\
\hline 2015 & 8,41 & 550.466 .868 & 4,96 & 8,27 \\
\hline 2016 & 7,63 & 572.554 .683 & 1,16 & 8,40 \\
\hline
\end{tabular}

Sumber: Badan Pusat Statistik Kabupaten Gowa, 2017

\section{TINJAUAN TEORITIK / LITERATURE REVIEW}

\section{Kemiskinan}

Thomas Maltus dalam Arsyad (2004) dan Dumairy dalam Todaro (2000) bahwa jumlah penduduk terlalu banyak atau kepadatan penduduk terlalu tinggi, atas menjadi penghambat pembangunan ekonomi di negara berkembang. Pendapatan per kapita dan tingkat pembentukan modal yang rendah semakin sulit bagi negara berkembang untuk 
Siti, Puspita Interelasi Pertumbuhan Ekonomi ...

menopang ledakan jumlah penduduk. Sekalipun output meningkat sebagai hasil teknologi yang lebih baik dan pembentukan modal, peningkatan ini akan ditekan oleh jumlah penduduk yang terlalu banyak. Alhasil, tidak ada perbaikan dalam laju pertumbuhan nyata dalam perekonomian.

Malthus mengemukakan secara teoritis bahwa hubungan antara pertumbuhan penduduk dan pembangunan ekonomi. Dalam tulisannya yang berjudul Essay on the Principle of Population ia melukisan konsep hasil yang menurunkan (concept of dimishing returns). Malthus menjelaskan kecenderungan umum penduduk suatu negara untuk tumbuh menurut deret ukur yaitu menjadi dua kali lipat setiap 30 - 40 tahun, sementara itu pada saat yang sama, karena hasil yang menurun dan faktor produksi tanah persediaan pangan hanya tumbuh menurut deret hitung. Pertumbuhan persediaan pangan tidak bisa mengimbangi pertumbuhan yang sangat cepat dan tinggi, maka pendapatan per kapita (dalam masyarakat tani didefinisikan sebagai produksi pangan per kapita) akan cenderung turun menjadi sangat rendah, yang menyebab-kan jumlah penduduk yang tidak pernah stabil, atau hanya sedikit di atas tingkat subsistem.

Menurut Dumairy menegaskan bahwa alasan penduduk dipandang sebagai penghambat pembangunan, dikarenakan jumlah penduduk yang besar dan dengan pertumbuhan tinggi, dinilai hanya menambah beban pembangunan. Jumlah penduduk yang besar akan memperkecil pendapatan perkapita menimbulkan masalah ketenagakerjaan. Menurut teori Malthus. Pertumbuhan penduduk yang pesat pada suatu negara akan menyebabkan terjadinya kemiskinan kronis. Malthus melukiskan suatu kecenderungan universal bahwa jumlah populasi di suatu negara akan meningkat sangat cepat menurut deret ukur. Sementara itu, karena adanya proses pertambahan hasil yang semakin berkurang disuatu faktor produksi yang jumlah tetap yaitu tanah, maka persediaan pangan hanya akan meningkat menurut deret hitung.

Pertumbuhan pengadaan pangan tidak dapat berpacu secara me-madai atau mengimbangi kecepatan perkapita (dalam masyarakat agraris, pen-dapatan perkapita diartikan sebagai produksi pangan perkapita) cenderung meng-alami penurunan sampai sedemikian rendahnya sehingga segenap populasi harus bertahan pada kondisi sedikit diatas tingkat subsistem. Seseorang dikatakan miskin atau hidup dalam kemiskinan jika pendapatan atau aksesnya terhadap barang dan jasa relatif rendah dibandingkan rata-rata orang lain dalam perekonomian tersebut. Todaro (1989), mengemukakan bahwa yang 
menyebabkan kemiskinan di negara berkembang disebabkan oleh beberapa faktor yaitu: 1) perbedaan geografi, jumlah peduduk, dan tingkat pendapatan, 2) perbedaan sejarah, sebagai dijajah oleh negara berlainan, 3) perbedaan kekayaan sumber daya alam dan kualitas sumber daya manusianya, 4) perbedaan peranan sektor swasta dan negara, 5) perbedaan struktur industri, 6) perbedaan derajat ketergangguan pada kekuatan ekonomi dan politik dan kelembagaan dalam negara.

Namun, hal tersebut cukup berbeda dengan menurut Stiglitz (2011) tentang terminologi kemiskinan, yang melihat kemiskinan dalam perspektif yang lebih multidimensional. Dimensi-dimensi pokok yang harus diperhitungkan adalah (1) standar hidup materiil (pendapatan, konsumsi, dan kekayaan; (2) kesehatan; (3) pendidikan; (4) aktivitas individu, termasuk bekerja; (5) suara politik dan tata pemerintahan; (6) hubungan dan kekerabatan sosial; (7) lingkungan hidup (kondisi masa kini dan masa depan); dan kualitas hidup masyarakat.

Badan Pusat Statistik (BPS) yang mengukur kemiskinan dengan menggunakan konsep kemampuan memenuhi kebutuhan dasar (Basic needs pooroach). Dengan pendekatan ini, kemiskinan dipandang sebagai ketidakmampuan dari sisi ekonomi untuk memenuhi kebutuhan dasar makanan dan bukan makanan diukur dari sisi pengeluaran. Jadi penduduk miskin adalah penduduk yang memiliki rata-rata pengeluaran perkapita perbulan dibawah garis kemiskinan. Garis kemiskinan merupakan penjumlahan dari Garis Kemiskinan Makanan (GKM) dan Garis Kemiskinan Non Makanan (GKNM). Penduduk yang memiliki ratarata pengeluaran perkapita per bulan dibawah garis kemiskinan dikategorikan sebagai penduduk miskin. Garis Kemiskinan Makanan (GKM) adalah nilai pengeluaran kebutuhan minimum makanan yang disertakan dengan 2.100 kilokalori perkapita per hari. Paket komoditi kebutuhan dasar makanan diwakili oleh 52 jenis komoditi (padi-padian, umbiumbian, ikan, daging, telur dan susu, sayur, kacang-kacangan, buah-buahan, minyak dan lemak, dan lain-lain). Garis Kemiskinan Non Makanan (GKNM) adalah kebutuhan minimum untuk perumah-an, sandang, pendidikan dan kesehatan. Paket komoditi kebutuhan dasar non makanan diwakili oleh 51 jenis komoditi di perkotaan dan jenis komoditi di pedesaan. Rumus perhitungan garis kemiskinan (BPS) adalah : 
Siti, Puspita Interelasi Pertumbuhan Ekonomi ...

$\mathrm{GK}=\mathrm{GKM}+\mathrm{GKNM}$

Ket :

GK = Garis Kemiskinan

GKM $=$ Garis Kemiskinan Makanan

GKNM $=$ Garis Kemiskinan Non Makanan

Garis kemiskinan merupakan respresentasi dari jumlah rupiah minimum yang dibutuhkan untuk memenuhi kebutuhan pokok minimum makanan yang setara dengan 2.100 kilokalori per kapita per hari dan kebutuhan bukan makanan. BPS (Badan Pusat Statistik) menggunakan batas garis kemiskinan setara dengan 2.100 kalori perkapita per hari yang akan disetarakan dengan rupiah ketika pengukuran kemiskinan dilakukan di tiap daerah/propinsi dengan menyesuaikan harga yang berlaku pada suatu daerah provinsi tertentu. Sehingga pengukuran kemiskinan pada daerah/provinsi akan menggunakan satuan rupiah dengan menyesuaikan harga pada tiap-tiap daerah tertentu.

\section{Teori Pertumbuhan Ekonomi}

Adam Smith dalam Boediono (1985) mengemukakan bahwa pertumbuhan ekonomi adalah proses kenaikan output perkapita dalam jangka panjang, dalam teori ekonomi klasik. Inti ajaran Smith adalah agar masyarakat diberi kebebasan seluas-luasnya dalam menentukan kegiatan ekonomi pasar bebas akan men-ciptakan efisiensi, membawa ekonomi kepada kondisi full employment, dan menjamin pertumbuhan ekonomi sampai posisi stasioner (stationary state). Posisi stasioner terjadi apabila sumber daya alam telah seluruhnya termanfaatkan. Kalau-pun ada pengangguran, hal itu bersifat sementara. Pemerintah tidak perlu terlalu dalam mencampuri urusan perekonomian. Tugas pemerintah adalah menciptakan kondisi dan menyediakan fasilitas yang mendorong pihak swasta berperan optimal dalam perekonomian. Pemerintah tidak perlu terjun langsung dalam kegiatan produksi dan jasa. Peranan pemerintah adalah menjamin keamanan dan ketertiban dalam kehidupan masyarakat serta membuat aturan main yang memberi ke-pastian hukum dan keadilan bagi para pelaku ekonomi. Dalam hal ini pemerintah berkewajiban menyediakan prasarana sehingga aktivitas swasta menjadi lancar. 
Pandangan Smith kemudian dikoreksi oleh John Maynard Keynes (1936) dengan mengatakan bahwa untuk menjamin pertumbuhan yang stabil pemerintah perlu menerapkan kebijakan fiskal (perpajakan dan perbelanjaan pemerintah), kebijakan moneter (tingkat suku bunga dan jumlah uang beredar), dan pengawasan langsung. Ahli ekonomi setelah itu ada yang mendukung dan memperluaskan pandangan Smith danada yang mendukung dan memperluas pandangan Keynes. Kedua kelompok ini tetap mengandalkan mekanisme pasar. Perbedaannya adalah ada yang menginginkan peran pemerintah yang cukup besar tetapi ada pula yang menginginkan peran pemerintah haruslah sekecil mungkin. Walaupun ber-beda, kedua kelompok umumnya sependapat bahwa salah satu tugas negara adalah menciptakan distribusi pendapatan yang tidak terlalu pincang (ada kaitan dengan tingkat saving dan konsumsi) sehingga pertumbuhan ekonomi bisa menatap dan ber-kelanjutan. Belakangan baru disadari bahwa pemerinah perlu turun tangan untuk menydiakan jasa yang melayani kepentingan orang banyak ketika swasta tidak berminat menanganinya apabila tidak diberi hak khusus. Misalnya pembangkit tenaga listrik, telpon dan air minum. Swasta mungkin berminat menyediakan fasilitas ini apabila diberi hak monopoli dan karena hal itu mungkin tidak diterima oleh masyarakat, penanganan-nya diambil alih oleh pemerintah. Hal lain yang dianggap wajar pemerintah turun tangan adalah mengatur stok pangan agar tercipta harga yang stabil dalam kerangka ekonomi wilayah, ada pandangan Smith yang tidak bisa diterapkan sepenuhnya, misalnya tentang lokasi dari kegiatan ekonomi tersebut sesuai dengan tata ruang yang berlaku maka lokasi dari berbagai kegiatan sudah diatur dan kegiatan yang akan dilaksanakan harus memilih diantara lokasi yang diperkenankan.

Melengkapi teori Keynes, dimana Keynes melihatnya dalam jangka pendek (kondisi statis) sedangkan Harrod-Domar melihatnya dalam jangka panjang (kondisi dinamis). Teori Harrod-Domar didasarkan pada asumsi: a) Perekonomian bersifat tertutup, b) Hasrat menabung, c) Proses produksi memiliki koefisian yang tetap, dan d) Tingkat pertumbuhan angkatan kerja adalah konstan dan sama dengan tingkat pertumbuhan penduduk.

Teori pertumbuhan neoklasik dikembang-kan oleh Robert M. Solow dan T.W Swan (1956) dari Australia. Model Solow-Swan menggunakan unsur pertumbuhan penduduk, akumulasi capital, kemajuan teknologi dan besarnya output yang saling berinteraksi. 
Perbedaan utama dengan mode Harrod-Domar adalah dimasukkannya unsur kemauan teknologi dalam modelnya. Selain itu, Sollow-Swan menggunakan model fungsi produksi yang memungkinkan adanya substitusi antara capital $(K)$ dan tenaga kerja $(L)$. Dengan demikian syarat-syarat adanya pertumbuhan yang mantap dalam model Solow-Swan kurang restriktif disebabkan kemungkinan subsitusi antara model dan tenaga kerja. Hal ini berarti adanya fleksibilitas dalam rasio modal-output dan rasio modal-tenaga kerja.

4. Pengukuran akan kemajuan sebuah perekonomian memerlukan alat ukur yang tepat, beberapa alat ukur pertumbuhan ekonomi antara lain yaitu:

a) Produk Domestik Bruto (PDB). Produk Domestik bruto (PDB) atau Produk Domestik Regional Bruto (PDRB), merupakan jumlah barang dan jasa akhir yang dihasilkan oleh suatu perekonomian dalam satu tahun yang dinyatakan dalam harga pasar. Baik PDB atau PDRB merupakan ukuran yang global sifatnya, dan bukan merupakan alat ukur ekonomi yang tepat, karena belum dapat mencerminkan kesejah-teraan penduduk yang sesungguhnya, padahal sesungguhnya ke-sejahteran harus dinikmati oleh setiap penduduk di negara atau daerah yang bersangkutan.

b) Produk Domestik Bruto per Kapita/Pendapatan per Kapita. Produk Domestik Bruto Per Kapita atau Produk Regional Bruto (PDRB) per kapita pada skala daerah dapat digunakan sebagai pengukur per-tumbuhan ekonomi yang lebih baik karena lebih cepat mencerminkan kesejahteraan produk suatu negara dari pada nilai PDB atau PDRB saja. Produk domestik bruto per kapita baik tingkat nasional maupun di daerah adalah jumlah PDB nasional maupun PDRB suatu daerah dibagi dengan jumlah penduduk di negara manapun didaerah yang bersangkutan, atau dapat disebut juga sebagai PDB atau PDRB rata-rata.

c) Menurut Todaro (2000), perlunya peninjauan kembali terhadap prioritas pembangunan di seluruh Negara berkembang, yakni dari yang semula berorientasikan kepada maksimalisasi laju pertumbuhan PDB/GNP ke tujuan yang mengutamakan kepentingan masyarakat yang lebih luas dan langsung, seperti halnya pengentasan kemiskinan serta pengurangan kesenjangan pendapatan. Namun disadari penin-jauan kembali tersebut untuk perbaikan nasib golongan miskin akan dihadapkan pada berbagai masalah dan kepada politik, kelembagaan, dan hal lainnya yang berkaitan dengan struktur kekuasaan. Meskipun laju pertumbuhan ekonomi tidak secara otomatis memberi jawaban 
atas berbagai macam pertanyaan dan masalah kesejahteraan, namun hal tersebut tetap merupakan unsur penting dalam program pembangunan yang dirancang untuk mengentaskan kemiskinan.

Berbagai penelitian yang dilakukan oleh para ekonom telah mencatat bahwa pertumbuhan ekonomi berperan penting dalam penurunan tingkat kemiskinan jangka panjang. Pertumbuhan ekonomi yang cepat dan pemerataan distribusi pen-dapatan harus dipisahkan sebagai tujuan-tujuan pembangunan. Kedua hal tersebut kadang tidak bisa secara barsama-sama tumbuh, pertumbuhan ekonomi yang tinggi belum tentu menjamin distribusi pendapatan yan lebih baik. Menurut Todaro, pertumbuhan ekonomi yang cepat dan distribusi pendapatan yang lebih merata bisa saja sekaligus diraih, dan ada beberapa Negara yang mampumem-buktikannya. Pertumbuhan ekonomi dan distribusi pendapatan harus berjalan secara bersama-sama. Pilihan yang diambil adalah bukan strategi pembangunan yang me-maksimalkan pertumbuhan ekonomi yang cepat, yang hasilnya hanya dinikmati oleh segelintir orang kaya di dalam suatu Negara tertentu atau bukan juga strategi yang menitik beratkan pada distribusi pendapatan yang lebih merata, tetapi kedua hal tersebut penting untuk diraih secara bersama-sama.

Dumairy (1996), sebagai organisasi atau rumah tangga, pemerintah melakukan banyak sekali pengeluaran untuk membiayai kegiatan-kegiatannya. Pengeluaranpengeluaran tersebut bukan saja untuk menjalankan roda pemerintah sehari-hari. Akan tetapi juga untuk membiayai kegiatan perekonomian. Bukan berarti pemerintah turut berbisnis meskipun hal ini sangat sering dilakukan, terutama oleh pemerintah di negaranegara sedang berkembang, melainkan dalam arti pemerintah harus menggerakan dan merangsang kegiatan ekonomi secara umum. Pemerintah harus merintis dan menjalankan kegiatan ekonomi yang masyarakat atau kalangan swasta tidak tertarik untuk menjalankannya. Di negara manapun selalu ada campur tangan atau investasi pemerintah dalam perekonomian. Tidak ada pemerintah yang dalam peraturan ekonomi negerinya berperan sebagai "wasit" atau "polisi", yang hanya berfungsi membuat undang-undang dan peratur-an, untuk kemudian menjadi pelerai jika timbul masalah atau penyelamat bila terjadi kepanikan. 
Siti, Puspita Interelasi Pertumbuhan Ekonomi ...

Konsep pembentukan modal manusia dalam konteks investasi di bidang pendidikan mengandung sejumlah problema. Berapa banyak persediaan total modal manusia diperlukan. Seberapa besar laju akumulasinya. Jenis pendidikan apa yang harus diberikan sejauh mana dan kapan. Dan bagaimana hasil dari investasi pendidkan tersebut mesti diukur. Sulit untuk menaksir persediaan total modal manusia yang di-perlukan di suatu negara terbelakang. Kebutuhan akan modal manusia pada negera terbelakang dalam wujud orang yang berpendidikan itu masih kurang. Adalah tidak mungkin menerangkan secara konkrit laju pertumbuhan pembentukan modal manusia tersebut, sebagaimana lazimnya pada akumulasi modal fisik.

Suparmoko, (2003) mengungkapkan pola investasi di bidang pendidikan, hampir semua negara terbelakang memberikan prioritas tinggi pada pendidikan dasar yang secara cuma-cuma dan wajib. Namun, disisi lain pendidikan menengah mendapatkan prioritas rendah. Ini mengakibatkan ketimpangan pada lembaga pendidikan dan memberikan beban fisik pada fasilitas. Semakin meningkatnya peranan pemerintah ini semakin besarnya pengeluaran pemerintah di bidang pendidikan dalam proporsinya terhadap pendapatan nasional. Pengeluaran pemerintah dalam arti rill dapat dipakai sebagai indikator besarnya kegiatan pemerintah, yang dibiayai oleh pengeluaran pemerintah itu. Semakin besar dan banyak kegiatan pemerintah semakin besar pula pengeluaran pemerintah yang bersangkutan. Tetapi hendaknya kita sadari bahwa proporsi pengeluaran pemerintah terhadap Pendapatan Nasional Bruto (GNP) adalah suatu ukuran yang sangat kasar terhadap kegiatan peranan pemerintah dalam suatu perekonomian.

Melalui kedua peran ini, kecepatan dan ketepatan aktivitas ekonomi dimasyarakat dapat di dorong sehingga bisa diarahkan agar bermanfaat secara optimal bagi kesejahteraan masyarakat.Belanja pemerintah dalam bidang pendidikan adalah pengeluaran pemerintah yang diperuntukan bagi pendapatan urusan pemerintah, baik urusan wajib, pilihan, dan penanganannya dalam bagian atau bidang tertentu. Pengeluaran belanja ini dapat mendukung berbagai program dan kebijakan-kebijakan dalam stabilitas perekonomian national. 


\section{Komponen Belanja Pendidikan}

Salah satu problem yang paling menggelitik adalah masalah perkiraan produktivitas investasi di bidang pembentukan modal manusia, khususnya pendidikan. Para ahli ekonomi menyarankan kriteria berikut.

a) Kriteria Tingkat Pengembalian.Pendidikan sebagai investasi mempunyai dua komponen yaitu, komponen konsumsi masa depan dan komponen penghasilan masa depan.

b) Kriteria Sumbangan Pendidikan Pada Pendapatan Nasional Bruto. Menelaah sumbangan pendidikan pada pertumbuhan pendapatan nasional di Amerika Serikat menyimpulkan bahwa sumber yang dialokasikan pada pendidikan naik sekitar 6,5 kali dibandingkan dengan pendapatan konsumen dalam dolar, dibandingkan dengan pembentukan modal fisik bruto dalam dolar. Dengan kata lain, investasi dibidang pendidikan menyumbang 3,5 kali lebih banyak pada kenaikan pendapatan nasional bruto daripada investasi di bidang modal fisik. Solow et,al. (1966). Menyangkut faktor residual sumbangannya terhadap pertumbuhan total pendapatan nasional sebesar 31 persen. Ini karena pengaruh kuat kemajuan ilmu pengetahuan (20 persen) dan ekonomi skala yang timbul dari pertumbuhan pasar (11 persen). Sumbangan modal terhadap pertumbuhan ekonomi kurang diperhitungkan di dalam kriteria residual, karena kurang persediaan modal dalam mencakup investasi. Maka laju pertumbuhan akan lebih banyak berkaitan dengan kenaikan persedian modal dan sedikit dalam hal pengetahuan.

\section{Pengaruh Belanja Pendidikan Terhadap Tingkat Kemiskinan}

Kesejahteraan masyarakat suatu wilayah atau negara setidaknya ditentukan oleh dua hal:

a) Masyarakat mempunyai sumber nafkah atau sumber pendapatan yang me-madai, yaitu dengan mempunyai pekerjaan sesuai dengan kemampuan dan bakat yang dimilikinya.

b) Terpenuhnya pelayanan yang dibutuhkan masyarakat dari negaranya. Pelayan-an ini berupa tersedianya barang dan jasa kebutuhan publik (air, listrik, ke-sehatan, pendidikan, keamanan) dan hak-hak publik lainnya untuk dapat hidup layak. 
Siti, Puspita Interelasi Pertumbuhan Ekonomi ...

Mewujudkan kedua hal diatas, diperlukan kemampuan negara (pemerintah) untuk mengadakan berbagai sarana dan fasilitas publik dan jasa pelayanan kebutuhan masyarakat. Untuk menjalankan fungsi negara dan pemerintah seperti itu, diperlukan anggaran yang memadai untuk membiayai berbagai kebutuhan pencapaian tujuan bernegara. Pengeluaran Pemerintah dapat bersifat "exhaustive" yaitu merupakan pembelian barang-barang dan jasa dalam perekonomian yang dapat langsung dikonsumsi maupun dapat pula untuk menghasilkan barang lain lagi.

Di samping itu pengeluaran pemerintah dapat pula bersifat "transfer" yaitu berupa pemindahan uang kepada individu-individu untuk kepentingan sosial, kepada perusahaanperusahaan sebagai subsidi mungkin pula kepada negara lain sebagai hadiah (grants). Jadi "exhaustive expenditure" menghasilkan faktor-faktor produksi dari sektor swasta ke sektor pemerintah. Sedangkan "transfer payment" hanya menggeser tenaga beli dari unit-unit ekonomi yang satu kepada unit-unit ekonomi yang lain dan membiarkan yang terakhir ini menentukan penggunaan dari uang tersebut. Exhaustive expenditure dapat merupakan pembelian barang-barang yang dihasilkan oleh swasta, misalnya bahan makanan, bangunan, mesin dan sebagainya dan dapat pula pembelian itu dilakukan terhadap barangbarang yang dihasilkan oleh pemerintah sendiri seperti jasa-jasa guru, militer, pegawai negeri, dan sebagainya. Apakah dapat merangsang aktivitas ekonomi di masyarakat sehingga berkontribusi bagi kesejahteraan publik. Sebagai contoh, dalam menyusun rencana belanja, dampak yang dapat ditimbulkan oleh belanja ini di masyarakat harus dipikirkan. Berdasarkan uraian diatas, dapat disimpulkan bahwa belanja negara atau pemerintah berperan penting dalam pengentasan kemiskinan

\section{METODE PENELITIAN / METHODS}

Jenis penelitian ini adalah penelitian kuantitatif yang menjelaskan pengaruh variabel bebas (independen) terhadap variabel terikat (dependen). Penelitian ini dilakukan di Kabupaten Gowa dalam penelitian ini menjelaskan pengaruh variabel bebas yaitu : pertumbuhan ekonomi (PDRB), belanja pendidikan dan pengangguran terhadap variabel terikat yaitu kemiskinan. metode analisis yang digunakan dalampenelitian ini adalah regresi linier berganda. Analisis regresi berganda ini untuk mengetahuiseberapa besar pengaruh yang terjadi antara variabel independen dan variabel dependen, dengan pendekatan OLS 
(Ordinary Least Squere). Pada penelitian ini menggunakan aplikasi komputerberupa SPSS 23.

Berdasarkan penelitian sebelumnya, maka model dasar yang dipakai adalah model persamaanregresi linear berganda sebagai berikut:

$Y=\beta 0+\beta 1 X 1+\beta 2 X 2+\beta 3 X 3+\mu$

Untuk estimasi koefisien regresi, ditransformasikan kebentuk linear dengan menggunakan logaritma natural (Ln) guna menghitung nilai elastisitas dari masing-masing variabel bebas terhadap variabel terikat ke dalam model sehingga diperoleh persamaan sebagai berikut:

$\operatorname{Ln} Y=\beta 0+\beta 1 \ln X 1+\beta 2 \ln X 2+\beta 3 \ln X 3+\mu$

Keterangan:

Ln = = Logaritma Natural

Y1 = Kemiskinan (\%)

$\beta 0=$ Konstanta $/$ intersept

$\mathrm{X} 1=$ Pertumbuhan Ekonomi $(\%)$

$\mathrm{X} 2=$ Belanja Pendidikan (Milyar)

X3 = Pengangguran (\%)

$\beta 1, \beta 2, \beta 3$,

Koefisien regresi

$\mu \quad=$ error term (kesalahan pengganggu)

2. Teknik Pengujian Penelitian

Mencapai tujuan penelitian dan pengujian hipotesis, maka data yang di-peroleh dari hasil penelitian selanjutnya diolah dengan suatu analisis dengan kebutuhan peneliti. Data diolah 
Siti, Puspita Interelasi Pertumbuhan Ekonomi ...

secara statistik dengan menggunakan alat bantu SPSS 23. Penggunaan metode analisis regresi linear berganda memerlukan asumsi klasik yang secara statistik harus dipenuhi. Asumsi klasik yang digunakan dalam analisis regresi berganda tersebut meliputi asumsi normalitas, multikolinearitas, autokorelasi, dan heteroskedastisitas. Teknik pengolahan yang digunakan dalam penelitian ini, yaitu:

a) Uji Asumsi Klasik. Uji asumsi klasik adalah persyaratan statistik yang harus dipenuhi pada analisis regresi linear berganda yang berbasis Ordinary Least Square (OLS). Uji asumsi klasik terbagi menjadi empat yaitu:

(1) Uji Normalitas. Uji Normalitas bertujuan untuk menguji apakah dalam model regresi, variabel terikat dan variabel bebas keduanya mempunyai distribusi normal atau tidak. Model regresi yang baik adalah memiliki distribusi data normal atau mendekati normal. Metode yang dapat dipakai untuk normalitas antara lain: analisis grafik dan analisis statistik.

Uji normalitas dalam penelitian ini dilakukan dengan cara analisis grafik. Normalitas dapat dideteksi dengan melihat penyebaran data (titik) pada sumbu diagonal dari grafik atau dengan melihat histogram dari residualnya: a) Jika data menyebar di sekitar garis diagonal dan mengikuti garis diagonal atau grafik histogramnya menunjukkan pola distribusi normal regresi memenuhi asumsi normalitas; dan b) Jika data menyebar jauh dari garis diagonal dan atau tidak mengikuti arah garis diagonal atau grafik histogram tidak menunjukkan pola distribusi normal, maka model regresi tidak memenuhi asumsi normalitas.

(2) Uji Multikolinearitas. Uji multikolinearitas memeiliki tujuan untuk meng-uji apakah dalam model regresi ditemukan adanya korelasi antara variabel pertumbuhan ekonomi, belanja pemerintah, dan pengangguran. Model regresi yang baik tidak terjadi korelasi diantara variabel pertumbuhan ekonomi, belanja pemerintah, dan pengangguran. Gejala multikolinearitas dapat dideteksi dengan melihat nilai tolerance dan variance inflation faktor (VIF). Berdasarkan aturan variance inflation factor (VIF) dan tolerance, maka apabila VIF melebihi angka 10 atau tolerance kurang dari 10 atau tolerance lebih dari 0,10 maka dinyatakan tidak terjadi gejala multikolinearitas.

(3) Uji Autokorelasi. Uji autokorelasi bertujuan menguji apakah model regresi adanya korelasi antara kesalahan pengganggu pada periode t dengan kesalahan pengganggu pada periode t-1 (sebelumnya). Salah satu metode analisis untuk mendeteksi ada tidaknya autokorelasi adalah dengan me-lakukan pengujian nilai Durbin Watson (DW test). 
(4) Uji Heteroksedastisitas. Uji Heteroskedastisitas merupakan keadaan dimana varians dari setiap gangguan tidak konstan. Pengujian ini memiliki tujuan untuk menguji apakah dalam model regresi terjadi ketidaksamaan variance dari residual satu pengamatan yang lain atau untuk melihat penyebaran data. Jika variance dari residual atau pengamatan yang lain tetap, maka disebut Homokedastisitas dan jika berbeda disebut Hetero-skedastisitas.

Mengetahui adanya heterokedastisitas adalah dengan melihat ada atau tidaknya pola tertentu pada grafik Scatter Plot dengan ketentuan: a) Jika terdapat pola tertentu, seperti titik-titik yang ada membentuk pola tertentu yang teratur maka menunjukkan telah terjadi heterokedastisitas; b) Jika tidak ada pola yang jelas, serta titik menyebar di atas dan di bawah angka 0 pada sumbu $Y$, maka tidak terjadi heterokedastisitas sehingga model regresi layak di pakai.

b) Uji Hipotesis. Untuk mengetahui tingkat signifikansi dari masing-masing koefisien regresi variabel bebas (independen) terhadap variabel terikat (dependen) maka penulis menggunakan uji statistik sebagai berikut:

(a) Uji Simultan (Uji F). Uji F merupakan alat uji statistik secara bersama-sama atau keseluruhan dari koefisien regresi variabel pertumbuhan ekonomi, belanja pemerintah, dan pengangguran mempunyai pengaruh terhadap variabel kemiskinan. Dari uji $\mathrm{F}$ dapat diketahui apakah semua variabel pertumbuhan ekonomi, belanja pemerintah, dan pengangguran yang dimasukkan dalam model memiliki pengaruh secara bersama-sama atau tidak terhadap variabel kemiskinan. Hipotesis yang digunakan adalah:

(1) $\mathrm{H} 0: \beta 1=\beta 2=\beta 3=0$, berarti variabel pertumbuhan ekonomi, belanja pemerintah, dan pengangguran secara keseluruhan tidak berpengaruh terhadap variabel kemiskinan.

(2) Ha : $\beta 1 \neq \beta 2 \neq \beta 3 \neq 0$, berarti variabel pertumbuhan ekonomi, belanja pemerintah, dan pengangguran secara keseluruhan berpengaruh terhadap variabel kemiskinan.

(b) Uji Parsial (Uji t). Uji t dilakukan untuk mengetahui pengaruh masing-masing atau secara parsial variabel pertumbuhan ekonomi, belanja pemerintah, dan pengangguran terhadap variabel kemiskinan. Uji ini digunakan untuk membuat keputusan apakah hipotesis 
Siti, Puspita Interelasi Pertumbuhan Ekonomi ...

terbukti atau tidak, dimana tingkat signifikan yang digunakan dalam pengujian Uji t yaitu 5\%.Adapun dasar pengambilan keputusan yaitu Jika nilai signifikansi < 0,05 maka H0 ditolak Ha diterima dan Jika nilai signifikansi > 0,05 maka HO diterima Ha ditolak.

(c) Koefisien Determinasi (R2). Koefisien determinasi merupakan besaran yang menunjukkan besarnya variasi variabel Kemiskinan yang dapat di-jelaskan oleh variabel pertumbuhan ekonomi, belanja pemerintah dan pengangguran. Dengan kata lain, koefisien determinasi ini digunakan untuk mengukur seberapa jauh variabel-variabel bebas dalam menerang-kan variabel terikatnya. Hasil dari perhitungan koefisien determinasi dapat diperoleh dari hasil analisis regresi berganda dengan melihat nilai $\mathrm{R}$ Dan nilai koefisien determinasi R Square (R2).

\section{HASIL DAN PEMBAHASAN / DISCUSSION}

\section{Pengaruh Pertumbuhan Ekonomi terhadap Kemiskinan}

Hasil pengujian statistik variabel Pertumbuhan Ekonomi pada Tabel 4.10 menunjukkan bahwa Pertumbuhan Ekonomi berpengaruh negatif dan signifikan terhadap Kemiskinan, dengan tingkat signifikansinya $(0,013<0,05)$ yang lebih kecil dari taraf signifikansi sebesar 0,05 dan nilai koefisien $\beta_{1}$ sebesar -0.871 . Dengan penjelasan bahwa setiap peningkatan $1 \%$ variabel Pertumbuhan Ekonomi maka akan menurunkan tingkat kemiskinan sebesar 0,871\% dengan asumsi variabel lain dalam kondisi konstan (Cateris paribus).

Hasil pengujian statistik ini sesuai dengan hipotesis yang diajukan. Ada beberapa hal yang menyebabkan pengaruh pertumbuhan ekonomi terhadap kemiskinan justru negatif dan signifikan terhadap kemiskinan dikabupaten gowa tahun 2007-2016. Pertama, pemerintahan dikabupaten gowa berhasil memberikan perhatian terhadap aspek kualitas hidup masyarakat melalui capaian beberapa indikator makro pembangunan seperti indeks pembangunan manusia (IPM). Sementara itu dari sisi pengelolahan keuangan menunjukkan capaian yang sangat menggembirakan. Pemerintahan Kabupaten Gowa berhasil mempertahankan opini wajar tanpa pengecualian (WTP), dari badan pemeriksa keuangan.

Dari hasil penelitian yang dilakukan ini sejalan dengan penelitian yang dilakukan oleh Rohani (2016) dengan judul Pengaruh Pertumbuhan Penduduk, Pertumbuhan Ekonomi, Pengangguran Dan Inflasi Terhadap Tingkat Kemiskinan Diprovensi Sulawesi Selatan. Hasil penelitian tersebut menunjukkan variable pertumbuhan penduduk, pertumbuhan ekonomi, 
pengangguran, dan tingkat inflasi secara simultan berpengaruh signifikan terhadap tingkat kemiskinan diprovinsi Sulawesi selatan. Dan secara parsial variabel pertumbuhan penduduk (X1) dan tingkat inflasi (X4) berpengaruh positif dan signifikan terhadap tingkat kemiskinan di provinsi Sulawesi selatan. Sedangkan variabel pertumbuhan ekonomi (X2) berpengaruh negatif dan signifikan terhadap tingkat kemiskinan di provinsi Sulawesi selatan. Dan variabel pengangguran (X3) berpengaruh positif dan tidak signifikan terhadap tingkat kemiskinan diprovinsi Sulawesi selatan.

\section{Pengaruh Belanja Pendidikan terhadap Kemiskinan}

Hasil pengujian statistik variabel Belanja Pendidikan pada data sebelumnya, menunjukkan bahwa Belanja Pendidikan berpengaruh negatif dan signifikan terhadap Kemiskinan, dengan tingkat signifikansinya $(0,053<0,05)$ yang lebih kecil dari taraf signifikansi sebesar 0,05 dan nilai koefisien $\beta_{1}$ sebesar 0.236 . Dengan penjelasan bahwa setiap peningkatan $1 \%$ variabel Belanja Pendidikan maka akan menurunkan tingkat Kemiskinan sebesar 0,236\% dengan asumsi variabel lain dalam kondisi konstan (Cateris paribus).

Adapun menurut Suparmoko (2003), semakin meningkatnya peranan pemerintah ini semakin besarnya penge-luaran pemerintah di bidang pendidikan dalam proporsinya terhadap pendapatan nasional. Pengeluaran pemerintah dalam arti rill dapat dipakai sebagai indikator besarnya kegiatan pemerintah, yang dibiayai oleh pengeluaran pemerintah itu. Semakin besar dan banyak kegiatan pemerintah semakin besar pula pengeluaran pemerintah yang bersangkutan. Tetapi hendaknya kita sadari bahwa proporsi pengeluaran pemerintah terhadap Pendapatan Nasional Bruto (GNP) adalah suatu ukuran yang sangat kasar terhadap kegiatan peranan pemerintah dalam suatu perekonomian.

Menurut Dumairy (1996), sebagai organisasi atau rumah tangga, pemerintah melakukan banyak sekali pengeluaran untuk membiayai kegiatan-kegiatannya. Pengeluaranpengeluaran tersebut bukan saja untuk menjalankan roda pemerintah sehari-hari. Akan tetapi juga untuk membiayai kegiatan perekonomian. Bukan berarti pemerintah turut berbisnis meskipun hal ini sangat sering dilakukan, terutama oleh pemerintah di negara- 
negara sedang berkembang, melainkan dalam arti pemerintah harus menggerakan dan merangsang kegiatan ekonomi secara umum.

Hasil pengujian statistik ini sesuai dengan hipotesis yang diajukan. Adapun yang menyebabkan pengaruh belanja pendidikan terhadap kemiskinan justru negatif dan signifikan terhadap kemiskinan dikabupaten gowa tahun 2007-2016. Yaitu pemerintah kabupaten gowa berhasil melakukan investasi dibidang pendidikan ini dibuktikan dari anggaran belanja pendidikan yang tiap tahunnya meningkat dan juga melalui program pendidikan gratis yang diselanggarakan selain itu pemerintahan kabupaten gowa melakukan sebuah inovasi dengan Sistem Kelas Tuntas Berkelanjutan (SKTB) yang terbukti dari angka indeks pendidikan yang tercatat semakin meningkat sejak program ini dimulai pada tahun 2011.

Dari hasil penelitian yang dilakukan ini sejalan dengan penelitian yang dilakukan oleh Asrianti (2017) menemukan secara simultan variabel pertumbuhan ekonomi, pengangguran berpengaruh signifikan terhadap kemiskinan di Indonesia tapi variabel belanja pemerintah tidak berpengaruh signifikan terhadapn kemiskinan di Indonesia dengan nilai signifikan sebesar 0,133 variabel pertumbuhan ekonomi, pengangguran berpengaruh signifikan terhadap kemiskinan di Indonesia tapi variabel belanja pemerintah tidak berpengaruh signifikan terhadap kemiskinan di Indonesia.

3. Pengaruh Pengangguran terhadap Kemisikinan

Sebagaimana hasil pengujian statistik variabel Pengangguran pada tabel yang menunjukkan bahwa pengangguran berpengaruh positif dan signifikan terhadap kemiskinan, dengan tingkat signifikansinya $(0,047<0,05)$ yang lebih kecil dari taraf signifikansi sebesar 0,05 dan nilai koefisien $\beta_{1}$ sebesar 0.618 . Dengan penjelasan bahwa setiap peningkatan $1 \%$ variabel Pengangguran maka akan meningkatkan Kemiskinan sebesar 0,618\% dengan asumsi variabel lain dalam kondisi konstan (Cateris paribus).

Hasil pengujian statistik ini sesuai dengan hipotesis yang diajukan, dan sesuai dari aspek teoritis menurut Menurut Mankiw (2007), pengangguran adalah masalah makro ekonomi yang mempengaruhi manusia secara langsung dan merupakan masalah yang paling berat. Bagi kebanyakan orang, kehilangan pekerjaan berarti penurunan standar kehidupan dan tekanan psikologis. Jadi tidaklah mengejutkan jika peng-angguran menjadi topik yang sering dibicarakan dalam perdebatan politik dan para politisi seiring mengklaim bahwa kebijakan yang mereka tawarkan akan membantu menciptakan lapangan pekerjaan.

Adapun Menurut Sukirno (2004), adapun yang menyebabkan pengaruh pengangguran terhadap kemiskinan justru positif dan signifikan terhadap kemiskinan 108 
dikabupaten gowa tahun 2007-2016. Pemerintah kabupaten gowa berhasil meningkatkan aspek kualitas hidup masyarakat melalui capaian indikator pembangunan yaitu salah satunya angka pengangguran. Berdasarkan data bps pada tahun 2015 sebesar 4,96\% dan menurun pada tahun 2016 sebesar 1,16\%. Dari hasil penelitian yang dilakukan ini sejalan dengan penelitian yang dilakukan oleh Seri (2016) menemukan bahwa pertumbuhan ekonomi berpengaruh negatif terhadap tingkat kemiskinan di Indonesia tahun 1995-2014, pengangguran berpengaruh positif terhadap tingkat kemiskinan di Indonesia tahun 19952014, belanja pemerintah berpengaruh negatif terhadap tingkat kemiskinan di Indonesia 1995-2014, investasi tidak berpengaruh terhadap tingkat kemiskinan di Indonesia tahun $1995-2014$

\section{KESIMPULAN / CONCLUSION}

Berdasarkan hasil analisis data yang dilakukan dan pembahasan yang telah dikemukakan, maka diperoleh kesimpulan bahwa pertumbuhan ekonomi berpengaruh negatif dan signifikan terhadap kemiskinan. Selanjutnya, belanja pendidikan nampaknya berpengaruh negatif dan signifikan terhadap kemiskinan. Dan pengangguran berpengaruh positif dan signifikan terhadap kemiskinan. Dengan demikian, melihat situasi tersebut maka pemerintah mesti mendorong pertumbuhan ekonomi yang lebih merata atau lebih ingklusif, dengan mengupayakan penggarapan pembangunan yang lebih inklusif. Selain itu, melihat besarnya pengeluaran pemerintah setiap tahun, maka pemerintah harus memperhatikan alokasi dari belanja pendidikan agar bisa digunakan sebaik mungkin dan lebih transparan. Terakhir, pemerintah sebaiknya mengupayakan pelatihan peningkatan keterampilan agar dapat memanimalisir penganguran yang ada.

\section{DAFTAR PUSTAKA / REFERENCES}

Arsyad, Lincolin. 2004. Ekonomi Pembangunan. Edisi Keempat. Yogyakarta : STIE YKPN.

Asrianti, 2017. Pengaruh Pertumbuhan Ekonomi, Pengangguran Dan Belanja Pemerintah

Terhadap Tingkat Kemiskinan Di Indonesia. UIN ; Makassar.

Dumairy. 1996. Perekonomian Indonesia. Jakarta.

Boediono. 1985. Demand For Money In Indonesia 1975 - 1984. Bulletin Of Indonesia Economic Studies, Vol. XXI.

Badan Pusat Statisik Provinsi Sulawesi Selatan. 2018. Sulawesi Selatan. 
Siti, Puspita Interelasi Pertumbuhan Ekonomi ...

Badan Pusat Statisik Kabupaten Gowa. 2018. Sulawesi Selatan.

Firman, Risa. (2016). Sejarah Pemikiran Ekonomi Ailran Ratex https://rizafirman.wordpress.com. Diakses: 29 Januari 2018.

Keynes, John Maynard. 1936. The General Theory of Employment Interst And Money.

London : Macmillan

Mankiw, N.Gregory. 2007. Makroekonomi, Ed.6. Jakarta: Erlangga

Nanga, Muana. 2001.Makroekonomi: Teori, Masalah Dan Kebijakan, Cet.1. Jakarta: PT Raja Grafindo Persada.

Persaulian, Baginda, Hasdi Aimon dan Ali Anis.2013. "Analisis Konsumsi Masyarakat di Indonesia". Jurnal Kajian Ekonomi.

Rifdo.2012. Teori Konsumsi.http://rifdoisme.wordpress.com. Diakses : 4 Februari 2018.

Rohani. 2017. Pengaruh Pertumbuhan Penduduk, Pertumbuhan Ekonomi, Pengangguran Dan Inflasi Terhadap Tingkat Kemiskinan Di Provinsi Sulawesi Selatan. UIN ; Makassar.

Santoso ,Wijoyo, Sri Liani Suselo, Nurhemi dan Guruh Suryani R .2013. Pengaruh Hari Besar Pada Komoditas Utama Inflasi di Indonesia. Working Paper Bank Indonesia.

Seri. 2016. Analisis Pengaruh Pertumbuhan Ekonomi, Pengangguran, Belanja Pemerintah, Dan Investasi Terhadap Tingkat Kemiskinan Di Indonesia Tahun 1995 - 2014. Universitas Sanata Darma ; Yogyakarta.

Swan, T. W. 1956. Economic Growth and Capital Accumulation. Economic Records, 32 (1), 334-361

Stiglitz, Joseph E., Amartya Sen dan Jean Paul Seatoussi. 2011. Mengukur Kesejahteraan Mengapa Produk Domestik Bruto Bukan Tolok Ukur Yang Tepat Untuk Menilai Kemajuan. (Mutiara Arumsari dan Fitri Bintang Timur, Penterjemah). Bintaro: Marjin Kiri.

Sukirno, Sadono. 2004. Makro Ekonomi Teori Pengantar. Jakarta : PT. Raja Grafindu

Suparmoko (2003) Ekonomi Pembangunan. Edisi Keenam. Yogyakarta. BPFE. UGM

Todaro. 2000. Pembangunan Ekonomi Didunia Ketiga Edisi Ketujuh, Terjemahan Haris Munandar. Jakarta : Penerbit Erlangga.

Todaro, Michael. P. 1989. Pembangunan Ekonomi di Dunia Ketiga, Jakarta : PT Erlangga. 